
sex, and at Camden Town-The Secretary, Royal Veterinary College
(University of London), Royal College Street, London, N.W.1 (February 28).

SENIOR LECTURER or LECTURER (with appropriate teaching and research expcrience, and preferably with a medical qualification) IN THE SOHOOL of ANATOMY within the Faculty of Medicine-The Agent-General for New South Wales, 56 Strand, London, W.C.2; and Post Office, Kensington, N.S.W., Australia (Australia and Iondon, February 28).

CHAIr OF Physiology at Guy's Hospital Medical School-The Academic Registrar, University of London, Senate House, London, W.C.1 (March 1).

LEVERHULMe Postgraddate Fellows (3), two in the Factimy and one in the FACULTX OF FNGINFFRING-The liegistrar, The University, Iiverpool, quoting Ref. CV/600/T (March 1). LECTURER OF JUNIOR LECTURER IN MATHWMATICS-The Registrar, Crinity College, Dublin 2, Republic of Ircland (March 5)

LECTURER IN THEORETICAL PHYSICS-The Registrar (Room 22, o.R.B.), The University, Reading (March 10).

ASSISTANT LECTURER (preferably with a research interest in the theory of control or fluid dynamics) IN ENGINEERING MATIEMATICS-The Secretary, The Qucen's University, Belfast (Murch 12)

READER IN MicRobIOLOGY - The Registrar, University of $A$ delaide. Adelaide, South Australia (March 12)

LECTURER OF SENIOR LECTURER IN ZOOLOGY at the University of Melbourne, Australia-The Secretary, Association of Universities of
tho British Commonwealth (Branch Oflice), Marlborough House, Pall Mall, Iondon, S.W.1 (Australia and London, March 15),

SENIOR LECTURER IN THE DEPARTMENT OF GEOGRAPHY, University of the Witwatersrand, Johannesburg, South Africa-'The Secretary, Association of Universities of the British Commonwealth (Branch
Offlce), Marlborough House, Pall Mall, London, S.W.1 (South Africa Offlce), Marlborough Ho

and London, March 15).
CHAIR OF THEORETICAL PHYSICS in the Unjversity of Western Australia-The Secretary, Association of Universities of the Britisl Commonwealth (Branch office), Marlborough House, Pall Mall, London, S.W.1 (Australia and London, March 17).

SENIOR ILCTURER and an ASSISTANT LEC'TURER (preferably with medical qualiflcations) IN PHARMACOLOUY at the University of Hong Kong-The Secretary, Association of Universities of the British Commonwealth (Branch Oflice), Marlborough House, Pall Mall, Iondon, s.W.1 (Hong Kong and London, March 19),

SENIOR DEMONSTRATOR or LECTURER IN BOTANY (Plant Genetics) at the University of Melbourne, Australia-The Secretary, Association borough House, Pall Mall, London, S.W.1 (March 30).

DRUMMOND SENIOR FELLow, for research in nutrition-'The IIon. Secretary, Drummond Trust, University College, Gower Street, London, W.C.1 (April 10)

IMPERIAL CIEMICAL INDUSTRIES RHSWARCh FFLIOWE (preferably with a Ph.D. degree or equivalent research experience) IN Bto-

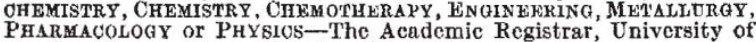

SENIOR LECTURRR or IECTURFR (graduate with an interest in physiological ecology or behaviour or comparative physiology) Is INVERTEBRATE PHYSTOLOGY in the Department of Zoology and Com parative Physiology, Monash University, Victoria, Australia-The Secretary, Association of Universities of the British Commonwealth
(Branch Office), Marlborough House, Pall Mall, London, S.W.1 (Branch Office), Marlborough Fo

ASTROPHYSICIST (with a Ph.J), degree and some obscrvatory ex. perience), to teach astronomy and related physies courses to undergraduates and postgraduates, and lo carry out astrophysical research attachments-Head of the Department of Physics, Queen's University, Kingston, Ontario, Canada.

GEOLOGIST (with a first- or second-class honours degree in geology) in Northern Rhodesia, for systematic geological mapping and the examination of economic deposits, etc. - The Director of Recruitment, Department of Technical Co-operation, Carlton Housc Terrace, London, S.W.1, quoting Ref. C1/RC.218/108/C1.

GRADUATE To THACH ChFMistRY to " $\mathrm{O}$ " and "A" level-The Headmaster, St. Edward's College, Sandfleld Park, Liverpool 12.

LECTUKER or ASSISTANT LECTURRR IN APTLISD MATHFMATICSThe Secretary, Queen Elizabeth College, Campden Hill Ioad, London, W.8.

LeCturke or Assistant Professor in Zoology; and a SENior DEMONSTRATOR IN ZOOLOGY-Prof. J. M. Honeyman, Sir George

Williams University, 1435 Drummond Strect, Montreal, Canada.

LEOTURER (with an honours degree in chemical cngincering or corporate member of the Institution of Chemical Fngineers, and experience in research and the operation and supervision of full-scale
chemical plant) IN CHEMIuAl ENaINEERIN(-The Registrar, The University, Nottingham

NATIONAL RESEARCH COUNCIL AND OTIER Postdoctoral FELLOWSurPs tenable in the Department of Physics--Prof. M. W. Johns Chairman, Department of Physics, McMaster University, Llamilton Ontario, Canada.

READER IN APPLIED MATHEMATICS-. The Clerk to the Governors.
Chelsea College of Science and Technology, Manresa Road, Jonion, Chelsea College of Science and Technology, Manresa Road, Jonion,
S.W.3.

RESEAROH Assistant (with a good honours degree or equivalent In physiology, biochemistry or zoology, and prefcrably expericnec in some field of hormone research or immunochemistry) IN THY PHYSIOLOGY DEPARTMENT, to study the physiology of prolactin with Institute for Research in Dairying (University of Reading), Shinfiek1, Institute for Research in Dairying (U

Reading, Berks, quoting Ref. 61/31.
SFNIOR LECTURER IN Brouog - The Secretary, The Royal College of Science and Technology, George Strcet, Glasgow, C.1.

THOHNICIAN or JUNIOR TWCHNician (preferably with biochemical experience) FOR THE RESEARCH DEPARTMENT OF IMMUNOLOAY School, Paddington, London, W.2.

\section{REPORTS and other PUBLICATIONS}

(not included in the monthly Books Supplement)

Great Britain and Ireland

Annual Report of the Medical Research Council of Ireland, 1960. $\mathrm{Pp}_{\text {T }}$ i +64 . (Dublin: Medical Research Council of Ireland, 1961.) [1411 The National Union of Teachers. University Entrance: The Basic
Facts. Third edition. Pp. 68. (London: The Natlonal Union of Facts. Third edition. Pp. 68. (London: The Natlonal Union of
Teachers, 1961.) 48. British Chemicals and their Manufacturers, 1961. Pp. 219. (London
Association of British Chemical Manufacturers, 1961.) Annual Report on the Metcorological Office for the ycar January 1 to December 31, 1960. Pp. B7+4 plates. (M.O. 710). (London: H.M. Stationery Oflice, 1961.) $4 s .6 d$. nct.
National Association for Mental Health. Annusl Report, 1960-1961. Np. 55. (London: National Association for Mental Health,
P. 1961.)
Thendon: National Association for Mental Health,
$[1711$ Pallis. Pp, $40+4$ plates. (Glasgow: Robert Maclchose and Co.; Ltdi., 1961.) Meeting, 11 th December 1961. Pp. 12. (London: Tube Investments

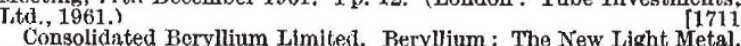
Consolidated Beryllium Limited. Beryllium: The New Light Metal. British Museum (Natural History). Economic Leaflet No 10: Ladybirds. Pp. 10. (London: British Museum (Natural History),
[201i

Other Countries

Acaúmic Royal de Belgique. Classe des Sciences. MemoiresDcuxième sèrie. Tome 15, Fascicule I: Le Massif Complexe Anorthosito-Leuconoritiquo de Haaland-Helleren et la Palingenése Basique. Par Dr. Jean Michot, Hr. Pp. $95+17$ planches. (Bruxelles : Académle
Royal de Belgique, 1961 .) 40 francs.
Smithsonian Miscellaneous Collections, Vol. 143, No. 5: A L Long. Smithsonian Miscellaneous Collections, Vol. 143, No. 5 : A Long
Range Temperature Forecast. By C. G. Abbot. Pp. i1 +46. (PublicaRange Temperature Forecast. By C. G. Abbot. Pp. I1 + 46. (PublicaMetropolitan Life Insurance Company. Statistical Bulletin, vol. 42 (September, 1981): International Mortality Trends at the Older Ages. Motor Vehicle Accidents. Pp. 12. (New York: Metropolitan I ife Insurance Company, 1961.) Pp. 12. (New York: Metropolitan 1141
[1411 United States Department of the Interior: Geological Survey. Bulletin 1096-B: Geology of the Cross Plains Quadrangle, Brown,
Callihan, Coleman, and Eastland Counties, Texas. By Philip T. Stafford. Pp. iv $+39-72+$ plates 4 and 5. (Washington, D.C. : Government Printing Office, 1960.) Canada: Department of Mines and Technical Surveys, Genloglcal Survey of Canada. Memoir 310: The Geology, Geochemistry, and Origin of the cold peposits of the Ycllowknife Distriet. 13y . W. W. Boyle. Pp. xvi $193+18$ plates. 2.50 dollars. Paper $61-7$ : Iron and Titanium in the Anorthosite of St. Urbain, Quebec. By Edward R. Rose. Pp, iv + 25 (2 plates). 50 cents. (Ottawa : Queen's Printer. 1960 and 1961.) United States Department of the Interior: Cenlogical Survey
Watcr-Supply Paper 1587: Water Resourees of the Raft River Basin Idaho-Utah. By R. T. Nuce. Pp. vi + $1.38+6$ plates. (Washington, D.C.: Government Printing Office, 1961.)
Occasional Yapers of the Natural History Museum of Stanford Occasional Yapers of the Natural History Museum of Stanford
University. No. 8: Discovery of the Snake Genus Opisthotropis in the Philippine Islands, with description of a New Species. By Walter C. Brown and Alan E. J,eviton. Pp. 5. No. 9: Description of a New
Subspecies of the Philippine Snake Dendrelaphis caudotineatus. By Subspecies of the Philippine Snake Dendrelaphis caudotineatus, By
Alan E. Leviton. Pp. 6. (Stanford, California : Natural History Nlan E. Leviton. Pp. 6. (Stanford, California : Natural History
Muscum of Stanford University, 1961.) Mational Research Council of Canada: Division of Building Rescarch Kuilding Research, 1960. Pp. 89 (4 plates). (NIRC 6463). (Ottawa

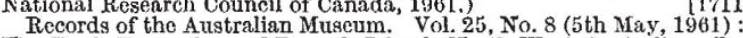
The Rock Fngravings of Depuch Island, North-West Australia. By Frederick D. McCarthy. Pp. 121-148+plates 9-15. (Sydney: The Australian Minseum, 1961.) Statc of California: Department of Fish and Gamc. Fish Bulletin No. 113: The Fcology of the Salton Sea, California, in Relation to the No. 114: An Evaluation of Stocking Hatchery-leared Steelhead Nainbow Trout (Salmo gairdnerii garrdnerí) in the Sacramento River System. By Richard J. Hallock, William. F. Van Wocrt, and Leo Game, 1961.)

-

Editorial and Publishing Offices of "NATURE"

MACMILLAN \& CO., LTD.

ST. MARTIN'S STREET, LONDON, W.C.2

Telephone Number: Whitehall 8831. Telegrams: Phusis Lesquare London

Annual subscription $£ 10$, payable in advance,

postage paid to any part of the world

Advertisements only should be addressed to

T. G. Scott \& Son, Led., I Clement's Inn, London, W.C.2 Telephone Number: Holborn 4743

All rights reserved. Registered as a newspaper at the General Post Office 